\title{
IAMJ
}

INTERNATIONAL

AYURVEDIC

MEDICAL JOURNAL

\section{EFFECT OF SRI LANKAN TRADITIONAL MEDICAL FORMULAE (KADUM BIDUM VEDAKAMA) ON FRACTURE HEALING (BHAGNA CHIKITSA) (AN OBSERVATIONAL CASE STUDY)}

\author{
$\underline{\text { Maduwanthi Anushika }}^{1}, \underline{\text { Waratenne, Prema Ranjani }}^{2}$ \\ ${ }^{1}$ Final year U.G Scholar, ${ }^{2}$ Senior Lecturer \\ Institute of Indigenous Medicine, University of Colombo, Rajagiriya, Sri Lanka
}

Corresponding Author: maduwanthianushika91@gmail.com

\section{https://doi.org/10.46607/iamj11p5012020}

(Published online: November 2020)

Open Access

(C) International Ayurvedic Medical Journal, India 2020

Article Received: 20/07/2020 - Peer Reviewed: 17/08/2020 - Accepted for Publication: 19/08/2020

Check for updates

\begin{abstract}
Distal radius fracture is one of the most common fractures with an incidence of 195.2/100,000 persons per year. The objective of this study was to observe the effect of different drug formulae used in traditional medicine in Sri Lanka for the fractures. 46 years old female patient with distal end radius fracture was selected from traditional orthopedic dispensary at Rathnapura district in Sri Lanka. Duration of the study was 5 weeks. It was observed that six prescriptions were used for the treatment. Improvements of main clinical features i.e. Sandhi Shula (Pain), Sandhi Shotha (local swelling), Sparsha Asahyathawa (local tenderness), Sandhi Hanthi (Impairment of functions) and Vikruthitha (Visible and palpable deformity) were analyzed by using prepared scoring system along with the line of treatment. Significant improvements were observed after the treatment. Pharmacodynamic properties of the main ingredients in the formulae support the rapid recovery of the presenting clinical features.
\end{abstract}

Keywords: Distal radius fracture, Bhagna Chikitsa, Traditional medicine. 


\section{INTRODUCTION}

A fracture is a broken bone. It can range from a thin crack to a complete brake. Bone can fracture crosswise, lengthwise in several places or into many pieces. Most fractures happen when a bone is impacted by more force or pressure than it can support ${ }^{1}$. Due to its prevalence worldwide, currently it is estimated that over 200 million people worldwide suffer from fracture and at least $40 \%$ of them are women $\& 15-35 \%$ of them are men. The main cause responsible for bone fracture in people all worldwide is the trauma. It has been shown that can initial fracture major risk factors for a new fracture. An increased risk of $86 \%$ for any fracture has been demonstrated in people that have already sustained a fracture ${ }^{2}$. The estimated prevalence in Sri Lanka to be $45 \%$. Other studies tested men for osteoporosis with one finding 5.8\% prevalence in men aged over 50 years \& another finding $4 \%$ prevalence in men aged 41- 47 year. According to national society the number of patients presenting fractures especially hip \& vertebral fractures, has increased in recent decades in Sri Lanka. One study using FRAX estimated the 10 years probability of a major fracture in Sri Lankan aged over 65 years to be $11 \%$ in men and $14 \%$ in women ${ }^{3}$. This case report provides evidence for treatment modes available for better outcomes of bone fracture in Sri Lankan traditional medical system. The treatment regimen which is described here was practiced by the eminent Sri Lankan traditional physician who belongs to "Sirimalwatte Abhayarama Wedaparamparawa" family.

\section{Case Study}

46 years old female patient presented with complain of severe pain, swelling, difficulties in flexion and extension of right wrist, at the traditional orthopedic dispensary on date 16.02.2019. On examination, movement of the fingers also restricted, and power was $1 / 5$; local tenderness; deformity of the wrist joint and fingers; abrasion were observed. Patient has a traumatic history with outstretch hand on the same day. Detailed history was taken but significant clinical history, like previous trauma, Diabetic or Hypertension etc. was not found as per the patient.
Treatment Plan: Duration of the treatment was five weeks. During this period six prescriptions were used. They are as follows, Prescription 01 (from Day 1 to Day 4): Pothu Malluma + Handi Thailaya + Thambuma, Method - Handi Thailaya was applied at the fracture site and wrapped the Handi Thaila bandage. Then, the Pothu Malluma was wrapped around it by using a bandage. After that two bamboo plates were kept on either side of the area and tied them with a bandage. Half cup of Thambuma was given internally twice a day before meals. Prescription 02 (from Day 5 to Day 11): Pothu Malluma + Handi Thailaya + Shulahara Thailaya + Thambuma, Method - Next 7 days same procedure was followed as above but Shulahara Thailaya mixed with Handi Thailaya. Prescription 03 (from Day 12 to Day 18) Kavalam Malluma + Handi Thailaya + Shulahara Thailaya + Thambuma, Method - Next 7 days also mixed oil (Handi Thailaya and Shulahara oil) bandage applied. Then, the Kavalam Malluma was wrapped around the fracture site and applied the bamboo plates on either side of the fracture area and tied them with a bandage. Thambuma was continued as above. Prescription 04 (from Day 19 to Day 22) Kavalam Malluma + Pani Paththuwa + Shulaharathailaya + Kubjaprasarani + Nirgundi Thaila + Mashabalarishtha + Thambuma. Method - First applied mixture of oil, i.e. (Kubjaprasarani, Nirgundi Thailaya and Shulahara Thailaya) and put the mixed oil bandage. Then Pani Pattuwa was applied over the bandage. Finally, Kavalam Malluma was wrapped around the bandage. Internally Thambuma was continued and Mashabalarishtha was given two table spoonfuls twice a day before meals. Prescription 05 (from Day 23 to Day 36) Pani Paththuwa + Mashabalarishtha-Method - Pani Paththuwa was applied on fracture site once a day for 10 days, at the home. Mashabalarishtha is continued

\subsection{Preparation of drugs}

All Pattu, Mallum, Thambuma and Handi Thailaya were prepared by the physician according to their own recipes at the Helabima Wedamadura, Hidallana, Rathnapura, Sri Lanka. Nirgundi Thaila, Kubja 
Prasarani Thaila, Shulahara Thaila and Mashabalarishtaya were purchased from Ayurveda Drug cooperation, Navinna, Sri Lanka.

\section{RESULTS AND DISCUSSION}

Information about the study and informed consent was taken before starting the research work. The efficacy of the treatment on selected five specific clinical signs was analyzed by using self-developed grading and scoring system.

Table 1: Grading and scoring system for Sandhi Shula (Pain)

No pain Occasional pain

Bearable pain

Unbearable pain

Unbearable and very discomfort

0
1
2
3
4

Table 2: Grading and scoring system for Sandhi Shotha (local swelling)

No swelling

Slight swelling ( $10 \%$ more than normal diameter)

Mild swelling ( $20 \%$ more than normal diameter)

Severe swelling (30\% more than normal diameter)

Extremely swelling ( $40 \%$ more than normal diameter)

0
1
2
3
4

Table 3: Grading and scoring system for Sparsha Asahyathawa (local tenderness)

\begin{tabular}{|l|l|}
\hline No tenderness & 0 \\
\hline Mild tenderness to palpation & 1 \\
\hline Mild tenderness with grimace and flinch to moderate palpation & 2 \\
\hline Severe tenderness with withdrawal & 3 \\
\hline Severe tenderness with withdrawal from noxious stimuli & 4 \\
\hline
\end{tabular}

Table 4: Grading and scoring system for Sandhi Hanthi (impairment of functions)

All the movements with Circumduction present

Dorsiflexion, palmar flexion, ulnar deviation and radial deviation present

Dorsiflexion, palmar flexion and ulnar deviation present

Dorsiflexion and palmar flexion present

Can't do any movement

0
1
2
3
4

Table 5: Grading and scoring system for Vikruthitha (visible and palpable deformity)

No deformity

Insignificant deformity

Small deformity

Moderate deformity

Severe deformity

\begin{tabular}{l|}
0 \\
1 \\
2 \\
3 \\
4 \\
\hline
\end{tabular}


Score of each clinical feature was noted before treatment and each visit to the dispensary. Mean score of each clinical feature was calculated for each week and shown in the Graph No. 01

Graph 1: Variation of the mean score for five weeks

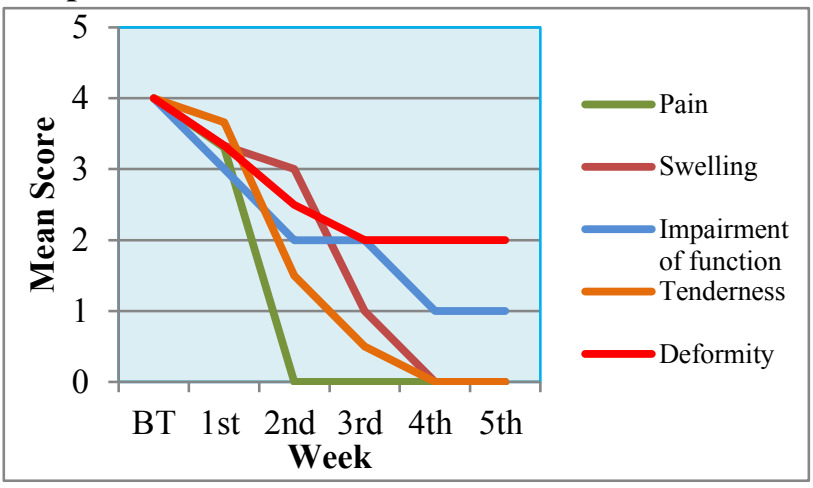

The pharmacodynamics properties of the herbs present in all recipes are having the combination of all Rasa, Guna, Veerya and Vipaka which pacify the all vitiated Doshas i.e. Vata, Pitta and Kapha which involved in the onset of clinical features of fractures and consequently the Asthi Dhathu.

In addition to that most of the herbs present in Pothu Malluma having Shothahara (relieving swelling), Vedana Sthapana (relieving pain), Vruna Ropana (wound healing), Vruna Shodana (cleaning wound) and Bhagna Sandhaniiya (fracture healing) properties. The herbs present in Kavalam Malluma (Mixture of Kola Malluma with Pothu Malluma) have the Shothagna (relieving swelling) and Shulagna (relieving pain) properties. Considering the herbs present in Pani Pattuwa most of the herbs in this formula have the Shothahara (relieving swelling), Vruna Shodana (cleaning wound), Vruna Ropana (wound healing) and Vedanahara (relieving pain) properties. Most of the herbs present in Handi Thailaya /Handi oil this formula having Shothahara (relieving swelling), Vedanasthapana (relieving pain), Vruna Shodana (cleaning wound) and Vruna Ropana (wound healing) properties $^{4}$. Most of the herbs present in Thambuma having Shothahara (relieving swelling), Vedana Sthapana (relieving pain) properties ${ }^{4}$.

\section{CONCLUSION}

Considering the effect of the five weeks treatment marked improvement was shown in pain, swelling and tenderness. But impairment of functions of the wrist joint was improved in moderate level and visible deformity was improved in mild level. Therefore, it can be concluded as the progress of the patient's condition is very effective and rapid; the treatment of the fractures by traditional medicine is safer and more beneficial.

\section{REFERENCES}

1. Anna Zernone Giorgi. Fracture Definition and Patient education.[Internet]. New York: Health line Media a Red Ventures Company;[updated 2017 July 8]. Available from:

https://www.healthline.com/health/fracture

2. Women over 50 will experience osteoporotic fractures. as will men. International osteoporosis foundation. [Internet]. $2013 . \quad$ Available from:https://www.iofbonehealth.org/contact-us

3. Asia_Pacific_Audit_SriLanka_0_0.pdf International osteoporosis foundation. [2013]. Available from: https:/www.iofbonehealth.org/epidemiology

4. Jayaweera. D.M.A. Medicinal plants (Indigenous and Exotic) used in Ceylon. The national science foundation, Sri Lanka. Colombo. 2006

\section{Source of Support: Nil \\ Conflict of Interest: None Declared}

How to cite this URL: Maduwanthi Anushika \& Waratenne, Prema Ranjani: Effect Of Sri Lankan Traditional Medical Formulae (Kadum Bidum Vedakama) On Fracture Healing (Bhagna Chikitsa) (An Observational Case Study). International Ayurvedic Medical Journal \{online\} 2020 \{cited November, 2020 $\quad$ Available from: http://www.iamj.in/posts/images/upload/2617_2620.pdf 